Forestry and Grassland Received on: 12/01/2021 Accepted on: 29/03/2021

\title{
Structure and nutritional value of BRS Zuri grass under shading
}

\author{
Estrutura e valor nutritivo do capim BRS Zuri sob sombreamento
}

1*JANUSCKIEWICZ, Estella Rosseto

https://orcid.org/0000-0002-6923-0897

${ }^{1}$ PAIVA, Luísa Melville

https://orcid.org/0000-0003-4726-943X

${ }^{1}$ FERNANDES, Henrique Jorge

https://orcid.org/0000-0001-7617-9711

${ }^{2}$ FLEITAS, Alex Coene

http://orcid.org/0000-0002-2637-0080
${ }^{3}$ DUARTE, Camila Fernandes Domingues http://orcid.org/0000-0002-9776-1353

${ }^{4}$ BISERRA, Thiago Trento

http://orcid.org/0000-0002-6130-9787

${ }^{1}$ GOMES, Patrícia dos Santos

http://orcid.org/0000-0001-5679-5904

\footnotetext{
${ }^{1}$ Universidade Estadual de Mato Grosso do Sul, unidade universitária de Aquidauana, Rodovia Graziela Maciel Barroso, Km 12 Zona Rural, 79200000, Aquidauana, MS, Brazil.

${ }^{2}$ Universidade Federal de Mato Grosso do Sul, Faculdade de Medicina Veterinária e Zootecnia, Av. Senador Felinto Muller, 2443, 79070-900, Campo Grande, MS, Brazil.

3 Universidade Federal de Rondonópolis, Av. dos Estudantes, 5055, 78736-900, Cidade Universitária, Rondonópolis, MT, Brazil.

${ }^{4}$ Fortuna Nutrição Animal, MT-320 km 198 Zona Rural, 78515-000, Nova Canaã do Norte, MT, Brazil.

* Mail for correspondence: estella_rosseto_janusckiewicz@yahoo.com.br
}

\section{ABSTRACT}

The objective was to determine the structural and nutritive parameters for Panicum maximum cv. BRS Zuri under a Eucalyptus shading system, in rainy and dry seasons. At the beginning of each season, the treatments (foliar fertilization levels of $0,3,6$ and $9 \mathrm{~L}$ $\mathrm{ha}^{-1}$ ) were applied and evaluated at 28,56 , and 84 growing days. The treatments did not affect significantly $(\mathrm{p} \geq 0.05)$ the evaluated parameters. The systems (shading and full sun) and seasons did not change $(\mathrm{p} \geq 0.05)$ forage and root masses. The leaf crude protein content was higher $(\mathrm{p} \leq 0.05)$ in the dry season. Height, leaf mass, stem and dead material, neutral and acid detergent fiber contents, and in vitro dry matter digestibility were affected $(\mathrm{p} \leq 0.05)$ by the system $\mathrm{x}$ season. The growing days did not affect $(\mathrm{p} \geq 0.05)$ forage mass. The mass of dead material decreased $(p \leq 0.05)$ over the evaluated intervals. The other parameters were affected $(\mathrm{p} \leq 0.05)$ by system $\times$ growing days. Based on the results, the forage and root masses show that the cv. BRS Zuri is adapted to the shading in the proposed experimental conditions. These masses added to the crude protein content indicate adaptation to low rainfall, inherent to the dry season, while foliar fertilization 
applied at the beginning of seasons did not affect the structural and nutritive parameters of BRS Zuri grass.

Keywords: foliar fertilizer, full sun, seasons, Panicum maximum, silvopastoral system

\section{RESUMO}

O objetivo foi determinar os parâmetros estruturais e de valor nutritivo do Panicum maximum cv. BRS Zuri sob sistema sombreado por eucalipto, nas estações chuvosa e seca. No começo de cada estação, os tratamentos (níveis de fertilização foliar de 0, 3, 6 and $9 \mathrm{~L} \mathrm{ha}^{-1}$ ) foram aplicados e as avaliações realizadas aos 28, 56 e 84 dias de crescimento. Os tratamentos não afetaram significativamente $(\mathrm{p} \geq 0.05)$ os parâmetros avaliados. Os sistemas (sombreado e a pleno sol) e estações não modificaram $(\mathrm{p} \geq 0.05)$ as massas de forragem e de raízes. O conteúdo de proteína bruta foi maior $(\mathrm{p} \leq 0.05)$ na estação seca. Altura, massas de folhas, colmos e material morto, conteúdos de fibra em detergente ácido e neutro, e digestibilidade in vitro da matéria seca foram significativamente afetados $(\mathrm{p} \leq 0.05)$ pela interação sistema $\mathrm{x}$ estação. Os dias de crescimento não afetaram $(\mathrm{p} \geq 0.05)$ a massa de forragem. A massa de material morto diminuiu $(\mathrm{p} \leq 0.05)$ com os intervalos de avaliação. Os outros parâmetros foram afetados $(\mathrm{p} \leq 0.05)$ pela interação sistema $\mathrm{x}$ dias de crescimento. Baseado nos resultados observados, as massas de forragem e raízes mostram que o cv. BRS Zuri é adaptado ao sombreamento proposto pelas condições experimentais. Essas massas, somadas ao conteúdo de proteína bruta indica que o capim é adaptado a baixas precipitações, inerentes a estação seca; a fertilização foliar aplicada no começo das estações não afeta os parâmetros estruturais e de valor nutritivo do capim BRS Zuri.

Palavras-chave: estações, fertilizante foliar, Panicum maximum, pleno sol, sistema silvipastoril

\section{INTRODUCTION}

There is, currently, increasing demand for sustainable animal production systems. Integrated production systems are considered good options when pursuing sustainability and, among them, silvopastoral systems are promising alternatives due to tree shading benefits. For pastures, the advantages depend on tree age, spacing, and arrangement since they interfere with the degree of shading (Paciullo et al. 2014).

Assessments of forage morphophysiological characteristics under shade are important to understand the species response (Oliveira et al. 2013). It is also essential to know the changes that occur over the seasons, such as different temperatures and rainfall conditions. André et al. (2020) reported that edaphoclimatic variations influence forage production, as well as structural and morphological components.

The tolerance to shading has already been proven for some Panicum maximum cultivars, such as Mombasa (André et al. 2020) and Tanzania (Oliveira et al. 2013). Although the cv. BRS Zuri has rapid regrowth, is easier to handle, and promotes greater gains per animal than the Tanzania and Mombasa cultivars evaluated in Acre and Mato Grosso do Sul, respectively (Jank et al. 2017), there are a few studies in shade. The nutritional value is also modified by shading. Protein contents tend to 
increase with the increasing soil microbial activity, moisture, and nutrient mineralization (Paciullo \& Gomide 2019). The authors also cite that positive changes in nutritional value depend on factors such as forage species, shading level, and season. Xaraes grass (Urochloa brizantha) showed no difference in digestibility under natural light, as well as $30 \%$ and $60 \%$ light reduction, but presented higher concentrations of crude protein and ash, and lower neutral detergent fiber, hemicellulose and cellulose in the treatment with the greatest luminosity reduction (Barros et al. 2019).

Considering the importance of silvopastoral systems, it becomes necessary to improve the knowledge of how forage plants react to the changing environment. The proposal was to determine the structure and nutritional parameters for evaluating Panicum maximum cv. BRS Zuri development under a Eucalyptus shading system, fertilized via foliar, in rainy and dry seasons. Thus, the hypothesis was that shading could cause undesirable structural changes, such as increased stem mass, compensated, however, by the improved nutritional value.

\section{MATERIAL AND METHODS}

The experiment was conducted in Aquidauana, $\mathrm{MS}\left(20^{\circ} 27^{\prime} \mathrm{S}\right.$ and $55^{\circ} 40^{\prime} \mathrm{W}$, $170 \mathrm{~m}$ average altitude). The regional climate is Aw (tropical savannah), according to Köppen (Peel et al. 2007) and the soil is Ultisol sandy loam texture (EMBRAPA 2013).

The Panicum maximum cv. BRS Zuri forage was planted in two areas, one under a Eucalyptus (Eucalyptus grandis $\mathrm{x}$ Eucalyptus urophylla hybrids) shading system and another in full sun. In both systems, the treatments consisted of three foliar fertilization levels as follows, Quimiorgen Pasto® $\left(3,6\right.$, and $\left.9 \mathrm{~L} \mathrm{ha}^{-1}\right)$ with $2 \mathrm{~L} \mathrm{ha}^{-1}$ Niphokam ${ }^{\circledR}$, plus the control (without Quimiorgen Pasto ${ }^{\circledR}$ ). The experimental period extended from August 2017 to March 2018, divided into dry and rainy seasons.

The design was a randomized block with 3 blocks and 4 plots per block, totaling 12 experimental units per system in each season. The data were analyzed as a $4 \mathrm{x}$ $2 \times 2$ factorial arrangement (four fertilizer levels $\mathrm{x}$ two systems $\mathrm{x}$ two seasons), considering data collected in each plot in each season, as timerepeated measures in the same unit.

The experiment implementation began in 2015 when matocompetition was controlled with post-emergent herbicide (3L ha ${ }^{-1}$ glyphosate) and harrowing. The soil chemical analysis indicated: $\mathrm{pH}$ in water 5.32; $15.85 \mathrm{~g} \mathrm{dm}^{-3}$ organic matter; $3.96 \mathrm{mg} \mathrm{dm}^{-3} \mathrm{P} ; 0.15 \mathrm{cmol} \mathrm{dm}^{-3} \mathrm{~K} ; 1.9$ cmol dm${ }^{-3} \mathrm{Ca} ; 1.0 \mathrm{cmol} \mathrm{dm}^{-3} \mathrm{Mg} ; 0.10$ cmol dm ${ }^{-3} \mathrm{Al} ; 2.68 \mathrm{cmol} \mathrm{dm}^{-3} \mathrm{H}+\mathrm{Al}$; $3.05 \mathrm{cmol} \mathrm{dm}^{-3}$ base sum, and $53.23 \%$ base saturation. So, limestone was applied followed by re-harrowing to incorporate the lime into the soil. Subsoiling between 30 and $40 \mathrm{~cm}$ deep was performed in the tree planting line of the shading system. Before planting, the Eucalyptus seedlings were treated with mono-ammonium phosphate $(1.5 \%)$ and imidacloprid-based insecticide $(0.5 \%)$. The tree seedlings were planted in E-W single rows, spaced 14 and $3 \mathrm{~m}$ between rows and trees, respectively, at the end of 2015. After planting, the I-144 and 1277 clones were fertilized with $80 \mathrm{~g}$ NPK plant-1 (06-30-06) and irrigated with approximately $4 \mathrm{~L}$ of water per plant. After 60 days, weed was controlled 
manually in the planting rows and with mechanical brushing between rows. Subsequently, the Eucalyptus trees were fertilized again with $80 \mathrm{~g}$ NPK plant-1 after 90 and 180 days (20-00-20), and 12 months (00-00-60). At the end of the experiment, the eucalyptus trees had a mean height of $11.98 \mathrm{~m}$ (ranging from 7.92 to $14.97 \mathrm{~m}$ ) and approximately two years of age.

The forage grasses were sown in November 2016 in both areas, which were divided into three blocks, with four experimental units per block, totaling 12 experimental units (10 $\mathrm{m} \times 9 \mathrm{~m}$ each) per system (shaded and full sun). Each experimental unit consisted of twenty forage rows sown using the recommended amount (g) that were irrigated until the plants could develop without irrigation and, from then on, $15 \mathrm{~cm}$-tall uniformity cuts were performed at the beginning of every season. Additionally, $2.4 \mathrm{D}$ herbicide was applied between rows in the experimental units to control weeds.

The experimental period started after the pastures were well established in August 2017. This period was divided into dry (82 days from August to November 2017) and rainy (88 days from December 2017 to March 2018) seasons. The average temperatures and accumulated rainfalls were $27.2^{\circ} \mathrm{C}$ and $183.6 \mathrm{~mm}$ and $26.6^{\circ} \mathrm{C}$ and $673.0 \mathrm{~mm}$ in the dry and rainy seasons, respectively. At the beginning of each season, one week after performing the uniform cut, the treatments were applied (to ensure enough leaf absorption area). The evaluations were carried in 28-dayintervals, at 28, 56, and 84 days of cultivation, considered growing days since no cutting or grazing took place in the intervals.
Three foliar fertilization levels using Quimiorgen Pasto® $\left(3,6\right.$, and $\left.9 \mathrm{~L} \mathrm{ha}^{-1}\right)$ with $2 \mathrm{~L} \mathrm{ha}^{-1}$ Niphokam ${ }^{\circledR}$, plus the control (without Quimiorgen Pasto ${ }^{\circledR}$ ), were evaluated. The Quimiorgen pasto ${ }^{\circledR}$ nutrient percentages and concentrations were as follows $20 \%$ and $270.0 \mathrm{~g} \mathrm{~L}^{-1}$ phosphorus $\left(\mathrm{P}_{2} \mathrm{O}_{5}\right) ; 0.5 \%$ and $6.75 \mathrm{~g} \mathrm{~L}^{-1}$ boron (B); $3 \%$ and $40.5 \mathrm{~g} \mathrm{~L}^{-1}$ manganese $(\mathrm{Mn})$, and zinc ( $\mathrm{Zn})$. Whereas, Niphokam ${ }^{\circledR}$ composition was $10 \%$ and $135.0 \mathrm{~g} \mathrm{~L}^{-1}$ nitrogen; $8 \%$ and $108.0 \mathrm{~g} \mathrm{~L}^{-1}$ $\mathrm{P}_{2} \mathrm{O}_{5}$ and potassium $\left(\mathrm{K}_{2} \mathrm{O}\right) ; 1 \%$ and 13.5 $\mathrm{g} \mathrm{L}^{-1}$ calcium $(\mathrm{Ca})$ and $\mathrm{Zn} ; 0.5 \%$ and 6.75 $\mathrm{g} \mathrm{L}^{-1}$ magnesium $(\mathrm{Mg}), \mathrm{B}$, and $\mathrm{Mn}$; and $0.2 \%$ and $2.70 \mathrm{~g} \mathrm{~L}^{-1}$ copper $(\mathrm{Cu})$.

In each experimental unit, the foliar fertilizer was applied using a $\mathrm{CO}_{2}$ pressurized backpack sprayer while the total amount applied was determined by equipment calibration, following the recommended $200 \mathrm{~L} \quad \mathrm{ha}^{-1}$ syrup (fertilizers plus water) and treatment levels. Fertilization was performed in the afternoon to avoid the day hottest hours while seeking higher humidity periods to favor fertilizer absorption by the leaves. Foliar fertilization occurred in early August and December 2017, respectively, for the dry and rainy seasons.

The evaluated structural parameters were average sward height and total mass of forage, leaves, stems, dead material, and roots and the nutritional parameters were contents of crude protein (CP), neutral detergent fiber (NDF), acid detergent fiber (ADF), and in vitro dry matter digestibility (IVDMD) of forage leaves. A cm-graduated ruler was used to measure the height in 20 random points in each experimental plot to calculate plot mean height and average sward height. Also, two forage samples were cut close to the soil using a $0.0625 \mathrm{~m}^{2}$ 
metal frame and divided into two subsamples. The first was weighed, dried in a forced circulation oven at $65{ }^{\circ} \mathrm{C}$ for $72 \mathrm{~h}$, and weighed again to obtain total dry matter. The other subsample was separated into leaves, stems, and dead material, which were weighed, ovendried at $65{ }^{\circ} \mathrm{C}$ for $72 \mathrm{~h}$ and weighed again. The total forage mass and that of the different morphological components were obtained from the fresh and dry weights. The evaluations occurred in September, October, and November 2017 (dry season) and January, February, and March 2018 (rainy season).

The roots in each experimental unit were sampled at points representing the average sward height measured the day before with a cm-graduated ruler. A steel cylinder $(15 \mathrm{~cm}$ tall and $15 \mathrm{~cm}$ diameter) was completely introduced into the soil for sampling the roots and shoots. First, the sampled shoot was cut at $5 \mathrm{~cm}$ from the ground then, the cylinder was completely introduced into the soil for root and soil removal. These samples were always collected between 6 and 10 $\mathrm{h}$ in the morning to avoid the variations of reserve carbohydrate contents (White 1973) and nitrogen compounds (Schjoerring et al. 2002) observed throughout the day in plant accumulation organs. Roots samplings occurred in October 2017 (dry season) and February 2018 (rainy season).

Soon after removal, the sampled roots (plus stem base) were packed in plastic bags and placed in a polystyrene box with ice to avoid losses of soluble compounds and, consequently, mass, and taken to the laboratory. Each sampled root was washed in running water over a $3 \mathrm{~mm}$ mesh sieve to clean the soil and frozen immediately (Cecato et al. 2001) for subsequent drying. After thawing, the samples were again washed to remove the remaining soil, weighed, dried at $65{ }^{\circ} \mathrm{C}$ for $72 \mathrm{~h}$, and reweighed. The root mass content was determined from the fresh and dry weights.

Besides the structural characteristics, the nutritional value was estimated as well. The sampled leaves were ground in a knife mill with $2 \mathrm{~mm}$ mesh sieves and sent to the laboratory to determine $\mathrm{CP}$, NDF and ADF contents, and IVDMD by the Near-Infrared Spectroscopy (NIRS) method. The evaluations occurred in September, October, and November 2017 (dry season) and January, February, and March 2018 (rainy season).

The data were analyzed as a $4 \times 2 \times 2$ factorial arrangement (four phosphate fertilizer levels $\mathrm{x}$ two systems $\mathrm{x}$ two seasons), considering the data collected in each plot in each season, as timerepeated measures in the same experimental unit. All interactions were evaluated, and removed from the model when not significant, or adequately unfolded.

The data were analyzed using PROC GLIMMIX from SAS University (SAS Institute Inc, Cary, Ca, USA) and, where appropriate, the minimum square means of the shading systems or the seasons were compared by the pdiff of the LSmeans command. When the effect of the fertilization levels was identified, the average fertilization levels were compared to the control using an adjustment for the Dunnett test in the pdiff option. In this case, the linear-toquadratic effects of the fertilizer levels used were also evaluated using orthogonal contrasts. A 5\% significance level was adopted for all statistical analyses. 


\section{RESULTS AND DISCUSSION}

The studied treatments did not affect significantly $(\mathrm{p} \geq 0.05)$ the evaluated parameters (Table 1), that is, the used foliar fertilizer levels were not enough to nourish the plants to the point of changing sward height and mass of forage, leaves, stems, dead material, and roots, as well as the contents of $\mathrm{CP}$, $\mathrm{NDF}, \mathrm{ADF}$, and IVDMD of leaves.

Table 1. Mean height $(\mathrm{cm})$, mass $\left(\mathrm{kg} \mathrm{DM} \mathrm{ha}^{-1}\right)$ of forage, leaves, stems, dead material and roots $(\% \mathrm{DM})$, as well as $\mathrm{CP}, \mathrm{NDF}, \mathrm{ADF}$, and IVDMD contents $(\%)$ for the control and different foliar fertilization levels.

\begin{tabular}{ccccc}
\hline & \multicolumn{4}{c}{ Foliar fertilization levels (L Quimiorgen $\mathbf{~ h a}^{-1}$ ) } \\
\cline { 2 - 5 } Parameters & $\mathbf{0}$ & $\mathbf{3}$ & $\mathbf{6}$ & $\mathbf{9}$ \\
\hline Height & 60.31 & 59.03 & 59.14 & 58.26 \\
Forage mass & 12513.00 & 12749.00 & 13227.00 & 13849.00 \\
Leaf mass & 6109.75 & 6355.11 & 5955.92 & 6296.83 \\
Stem mass & 3676.53 & 3650.53 & 3882.83 & 4540.33 \\
Dead material mass & 2727.19 & 2743.28 & 3388.44 & 3011.83 \\
Root mass & 20448 & 18515 & 17083 & 18137 \\
CP (\% DM) & 8.75 & 9.46 & 8.71 & 8.91 \\
NDF (\% DM) & 57.77 & 57.70 & 58.01 & 57.95 \\
ADF (\% DM) & 28.34 & 28.57 & 28.65 & 28.52 \\
IVDMD (\%) & 74.53 & 75.98 & 75.47 & 74.45 \\
\hline
\end{tabular}

*Means in the same row, followed by different letters, differ by T-test at $5 \%$.

** Standard error for mean height $=2.18 \mathrm{~cm}$; forage mass $=915.55 \mathrm{~kg} \mathrm{DM} \mathrm{ha}^{-1}$; leaf mass $=$ $367.53 \mathrm{~kg} \mathrm{DM} \mathrm{ha}^{-1}$; stem mass $=386.93 \mathrm{~kg} \mathrm{DM} \mathrm{ha}^{-1}$; dead material mass $=312.65 \mathrm{~kg} \mathrm{DM} \mathrm{ha}^{-1}$; root mass $=2298.90 \mathrm{~kg} \mathrm{DM} \mathrm{ha}^{-1} ; \mathrm{CP}$ content $=0.23 \%$; NFD content $=0.42 \%$, AFD content $=$ $0.28 \% ;$ IVDMD $=0.66 \%$.

These results do not mean that foliar fertilization is not efficient because the fertilizer was applied only once at the beginning of each season and, maybe a higher fertilization frequency could change these results significantly. Indeed, Garcia et al. (2017) studied Brachiaria radicans pastures and reported different results for a higher application frequency that compared a control treatment (no fertilization) with three foliar levels (1, 2 and 3, according to nutrient concentrations) and a granulate fertilizer, applied at 30,60 and 90 days after uniform cutting. These authors found that foliar fertilizer application 3 increased plant height
(4.2\% higher than the control) whereas foliar fertilizer 2 yielded lower heights (5.8\% less than the control). However, pasture quality did not improve with the use of different fertilizer types.

Foliar fertilization should be practiced in addition to and not to replace conventional fertilization. The soil must be able to supply nutrients from the time of forage sowing when nutrients can be absorbed only by the forming root system that grows more vigorously the more their demands at that moment are met. Foliar fertilization, however, is an important tool to supply micronutrients to plants. Pietroski et al. (2015) tested different nitrogen levels applied via 
foliar on Panicum maximum cv. Mombasa and reported increasing forage production and nitrogen accumulation, concluding that this is an important complementary practice to soil fertilization.

The shaded and full sun systems did not change $(p \geq 0.05)$ the forage and root masses (Figure 1), indicating that the BRS Zuri grass is well adapted to the shade since productivity was maintained under less light. Likewise, the forage and root masses did not change $(p \geq 0.05)$ significantly between seasons (Figure 2), allowing us to conclude that BRS Zuri grass adjusts to low precipitations as observed here in the dry season. The leaf $\mathrm{CP}$ content was affected ( $\mathrm{p} \leq 0.05)$ significantly, being higher $(\mathrm{p} \leq 0.05)$ in the dry season (Figure 2).

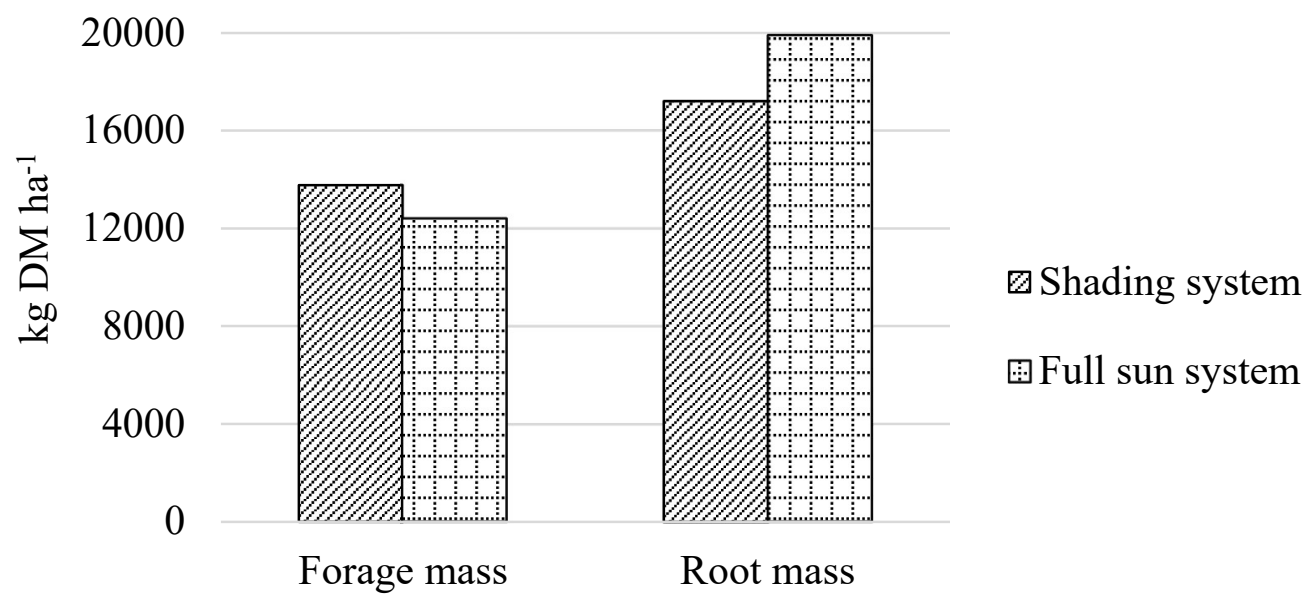

Figure 1. Mean forage and root masses for the systems.

* Means in the same parameter, followed by different letters, differ by the T-test at $5 \%$.

Figure 2. Mean forage and root masses, and leaf CP content for the seasons.
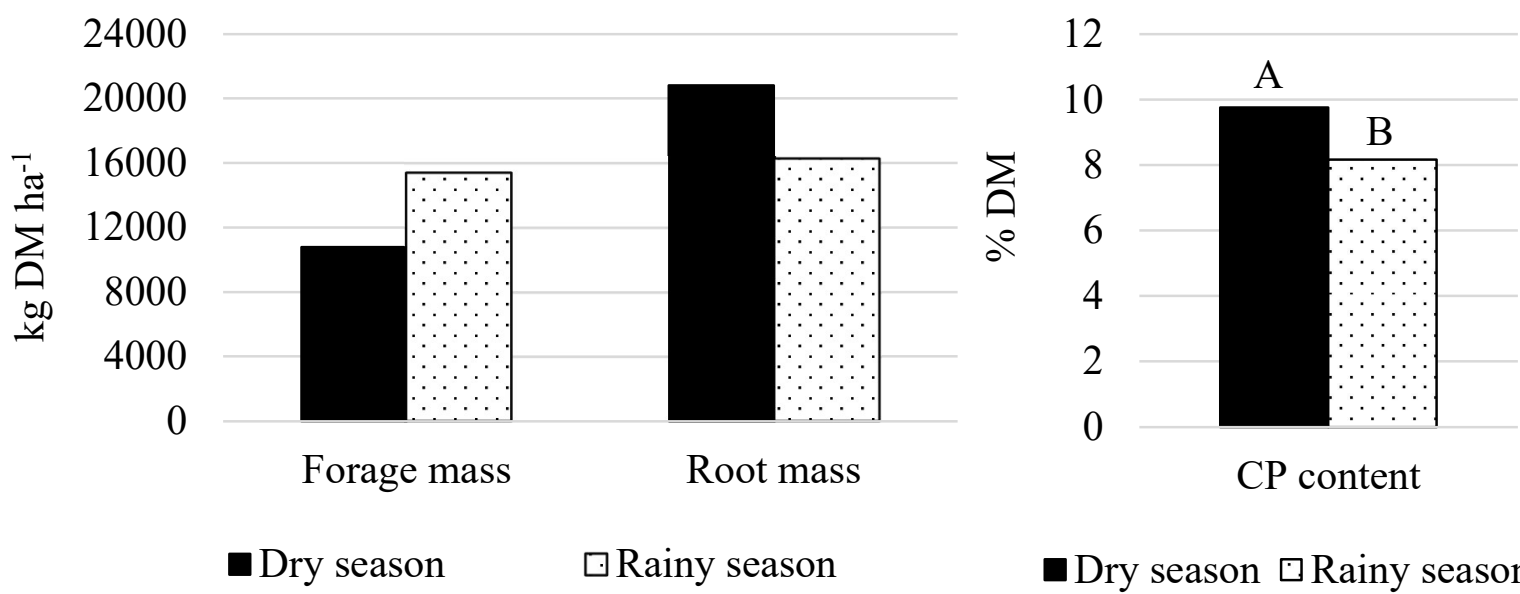

* Means in the same parameter, followed by different letters, differ by the T-test at $5 \%$. 
In this study, the lack of significant differences in forage and root production (Figures 1 and 2) indicates that the BRS Zuri grass has adapted to shading and different seasonal climatic conditions. However, we must consider that this statement is made for BRS Zuri pastures under shading of Eucalyptus grandis $\mathrm{x}$ Eucalyptus urophylla hybrids, spaced 14 $\mathrm{m}$ between rows and $3 \mathrm{~m}$ between trees, with an average height of $11.98 \mathrm{~m}$ (ranging from 7.92 to $14.97 \mathrm{~m}$ ). The same may not occur in other types of pasture under shading of other tree species (trees with other canopy areas and, consequently, shade area), age, and different spacing between trees. Examples of this are the research conducted by Favare et al. (2018) and Barragán-Hernández \& Cajas-Girón (2019).

Favare et al. (2018) observed that shading by pequi trees (average height of $10.22 \mathrm{~m}$ ) increases pasture production during drought and rain periods. These authors studied the dry matter yield of mixed pasture (Brachiaria brizantha Hochst Stapf cv. Marandu and cv. Xaraés; Panicum sp. cv Massai; Panicum maximum Jacq. cv. Mombasa) with Campo Grande Stylosanthes, wherein the pastures were inserted in the area where trees were pre-existing.

Barragán-Hernández \& Cajas-Girón (2019) observed that crude protein (CP) content of Megathyrsus maximus (Panicum maximum) cv. Mombasa was affected by the silvopastoral arrangement. The $\mathrm{CP}$ in the control (only pasture) and the treatment only shrubs were $2.42 \%$ lower than the means of the treatments that included tree strata by combining pastures, shrubs, and trees; and included the previous strata plus the inclusion of timber species.

Damage to the plant root system is expected under stressful situations such as grazing or cutting; as pastures grew freely during the experimental period, the root system was preserved. In the absence of defoliation, the forages did not need to relocate the reserve compounds (non-structural carbohydrates and nitrogen compounds) stored in the roots and stem bases to promote new growth of the shoot without altering the root system. The carbon that is not lost by the plant respiratory processes is stored as either starch or non-structural carbohydrates and used to maintain plant health in stressful situations, such as severe defoliation, or consumed during the reproductive stage (Lemaire 1997). In fast-growing species, carbohydrate concentration reduced significantly after defoliation, followed by rapid recovery, while carbohydrate concentration levels remained almost unchanged in slower-growing species (Atkinson et al. 2014).

Height and dead material mass were similar $(p \geq 0.05)$ for the shading and full sun systems (Table 2 ) in the dry season but higher $(\mathrm{p} \leq 0.05)$ in the shading system in the rainy season. However, the leaf and stem masses were higher $(\mathrm{p} \leq$ 0.05 ) in the full sun system in the dry season and similar $(\mathrm{p} \geq 0.05)$ in the rainy season (Table 2). 
Table 2. Mean and standard error of height, mass of leaves, stems, and dead material, and contents of NDF, ADF, and IVDMD of leaves, for system $\times$ season interaction.

\begin{tabular}{|c|c|c|}
\hline Season & Shading system & Full sun system \\
\hline & \multicolumn{2}{|c|}{ Height $(\mathrm{cm})$} \\
\hline Dry & $35.31 \pm 0.99$ & $33.18 \pm 0.99$ \\
\hline \multirow[t]{2}{*}{ Rainy } & $96.96 \pm 2.54 \mathrm{~A}$ & $71.30 \pm 2.54 \mathrm{~B}$ \\
\hline & \multicolumn{2}{|c|}{ Leaf mass $\left(\mathrm{kg} \mathrm{DM} \mathrm{ha}{ }^{-1}\right)$} \\
\hline Dry & $3556.97 \pm 293.40 \mathrm{~B}$ & $5399.83 \pm 293.40 \mathrm{~A}$ \\
\hline \multirow[t]{2}{*}{ Rainy } & $9059.94 \pm 415.60$ & $6700.86 \pm 415.60$ \\
\hline & \multicolumn{2}{|c|}{ Stem mass $\left(\mathrm{kg} \mathrm{DM} \mathrm{ha} \mathrm{ha}^{-1}\right)$} \\
\hline Dry & $2004.92 \pm 273.25 \mathrm{~B}$ & $3587.89 \pm 273.25 \mathrm{~A}$ \\
\hline \multirow[t]{2}{*}{ Rainy } & $6240.97 \pm 399.96$ & $3916.44 \pm 399.96$ \\
\hline & \multicolumn{2}{|c|}{ Dead material mass $\left(\mathrm{kg} \mathrm{DM} \mathrm{ha}^{-1}\right)$} \\
\hline Dry & $3443.06 \pm 192.40$ & $3571.11 \pm 192.40$ \\
\hline \multirow[t]{2}{*}{ Rainy } & $3254.14 \pm 233.01 \mathrm{~A}$ & $1602.44 \pm 233.01 \mathrm{~B}$ \\
\hline & \multicolumn{2}{|c|}{ Neutral detergent fiber (NDF, \% DM) } \\
\hline Dry & $55.21 \pm 0.36 \mathrm{~A}$ & $53.19 \pm 0.35 \mathrm{~B}$ \\
\hline \multirow[t]{2}{*}{ Rainy } & $60.51 \pm 0.38 \mathrm{~B}$ & $62.57 \pm 0.38 \mathrm{~A}$ \\
\hline & \multicolumn{2}{|c|}{ Acid detergent fiber (ADF, \% DM) } \\
\hline Dry & $27.00 \pm 0.23 \mathrm{~A}$ & $25.05 \pm 0.23 \mathrm{~B}$ \\
\hline \multirow[t]{2}{*}{ Rainy } & $30.65 \pm 0.29$ & $31.42 \pm 0.29$ \\
\hline & \multicolumn{2}{|c|}{ In vitro dry matter digestibility (IVDMD, \%) } \\
\hline Dry & $74.44 \pm 0.90 \mathrm{~B}$ & $77.71 \pm 0.89 \mathrm{~A}$ \\
\hline Rainy & $74.28 \pm 0.31$ & $73.98 \pm 0.31$ \\
\hline
\end{tabular}

*Means in the same row, followed by different letters, differ by the T-test at $5 \%$.

The NDF contents of leaves were higher $(\mathrm{p} \leq 0.05)$ in the shaded system compared to full sun in the dry season whereas the opposite was true in the rainy season (Table 2). Similarly, the ADF contents of leaves were higher $(\mathrm{p} \leq$ $0.05)$ in the shaded system compared to the full sun in the dry season (Table 2) while system percentages were similar $(\mathrm{p}$ $\geq 0.05$ ) in the rainy season. The IVDMD of leaves behaved similarly to the leaf and stem masses. Thus, IVDMD was higher $(\mathrm{p} \leq 0.05)$ in the full sun in the dry season and similar $(\mathrm{p} \geq 0.05)$ in the rainy season (Table 2).
The leaf and stem masses, IVDMDs as well as the NDF and ADF contents of leaves (Table 2) indicate that plants grown in full sun overcame more efficiently the inherent adverse climatic conditions of the dry season than those under the shaded system. Although the obtained stem mass and the number of leaves were higher $(p \leq 0.05)$ in the full sun system, these leaves had more IVDMD and lower NDF and ADF contents. The plants under full sun maintained the photosynthesis at levels sufficient to produce more nutritious leaves, avoiding compromising their quality by the unfavorable climatic 
conditions. On the other hand, the lower luminosity observed in the dry season, associated with shading, hindered the light incidence on the sward and the capture of wavelengths necessary for maximum photosynthetic activity. Therefore, the production of leaves and stems was impaired (Table 2), compromising the nutritive value of these leaves, which became more fibrous and had lower digestibility.

Morphogenetic changes are common in shaded tropical plants. In Panicum maximum cv. Tanzania and cv. Massai, the leaf elongation rate and blade length increased with shading, although the stem elongation rate was also stimulated (Paciullo et al. 2017) similar to the Brachiaria species as reported by (Paciullo et al. 2011). This growth also influences the behavior of forage grasses when less light penetrates the forage sward.

Despite leaf quality differences, the protein contents were similar for the two systems, but $\mathrm{CP}$ percentages differed between seasons, being significantly higher $(\mathrm{p} \leq 0.05)$ in the dry season
(Figure 2). Therefore, regardless of whether growing in full sun or shading, BRS Zuri grass can supply CP to the animals in the dry season when other forage plants are already compromised. In the rainy season, the leaf and stem masses, the ADF content and the IVDMD of the leaves were similar ( $\mathrm{p} \geq$ 0.05 ) for both systems, but height and dead material mass were higher $(\mathrm{p} \leq$ 0.05 ) in the shaded system (Table 2 ). This result demonstrates that senescence losses may occur when climatic conditions are favorable for growth, but the incident light into the forage sward is insufficient to promote enough photosynthetic rate for optimal plant development.

The growing days did not affect $(\mathrm{p} \geq$ 0.05 ) forage mass significantly (Figure 3) but influenced the dead material mass which decreased $(p \leq 0.05)$ over the evaluated intervals. After 28 growing days, the dead material mass was higher $(\mathrm{p} \leq 0.05)$ but similar $(\mathrm{p} \geq 0.05)$ to that obtained at $56(\mathrm{p} \geq 0.05)$ and 84 days. Thus, the dead material mass decreased over time (Figure 3).

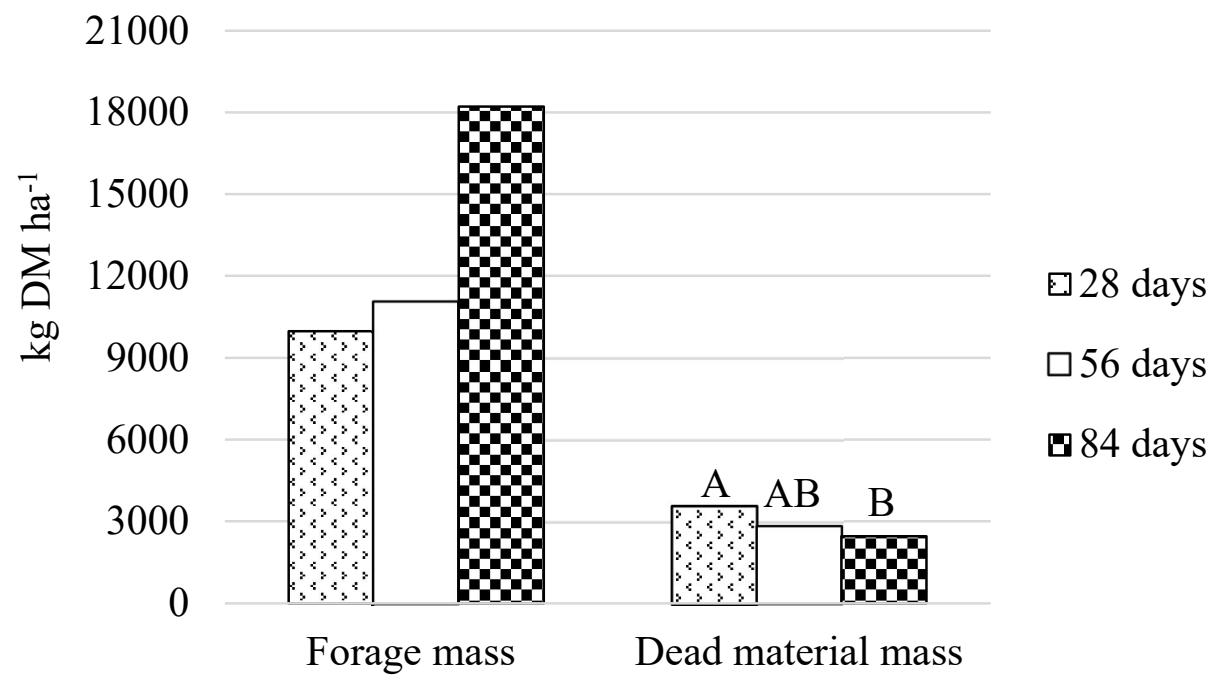

Figure 3. Mean forage and dead material masses for the growing days.

* Means in the same parameter, followed by different letters, differ by the T-test at 5\%. 
Over the time intervals evaluated, the biggest height $(\mathrm{p} \leq 0.05)$ was observed in the shaded system (Table 3 ). Leaf mass was similar ( $\mathrm{p} \geq 0.05)$ for both systems, on the first and last evaluation day. However, at 56 growth days, the leaf mass was higher $(\mathrm{p} \leq 0.05)$ in the full sun system than in the shading (Table 3 ). The dead material mass was also significantly affected $(p \leq 0.05)$ by the system $\times$ growing days interaction (Table 3 ), especially after unfolding this interaction, the means were similar $(\mathrm{p} \geq$ 0.05 ) between treatments after each growing day. The $\mathrm{CP}$ contents of leaves were similar $(p \geq 0.05)$ in the sun and shade at the beginning of the experimental period, differing only at 84 days when the percentage was higher ( $\mathrm{p}$ $\leq 0.05$ ) in the full sun (Table 3). The IVDMD of leaves was higher $(\mathrm{p} \leq 0.05)$ in the full sun after 28 and 84 growing days whereas no difference ( $\mathrm{p} \geq 0.05$ ) was observed at 56 days (Table 3 ).

Table 3. Mean and standard error of height, mass of leaves and stems, contents of CP, $\mathrm{NDF}, \mathrm{ADF}$, and in IVDMD of leaves, for system $\times$ growing days interaction.

\begin{tabular}{|c|c|c|}
\hline Growing days & Shading System & Full sun system \\
\hline & \multicolumn{2}{|c|}{ Height $(\mathrm{cm})$} \\
\hline 28 days & $41.22 \pm 0.95 \mathrm{~A}$ & $36.07 \pm 0.95 \mathrm{~B}$ \\
\hline 56 days & $58.75 \pm 1.44 \mathrm{~A}$ & $46.50 \pm 1.44 \mathrm{~B}$ \\
\hline \multirow[t]{2}{*}{84 days } & $98.42 \pm 3.72 \mathrm{~A}$ & $74.16 \pm 3.72 \mathrm{~B}$ \\
\hline & \multicolumn{2}{|c|}{ Leaf mass $\left(\mathrm{kg} \mathrm{DM} \mathrm{ha}{ }^{-1}\right)$} \\
\hline 28 days & $3585.50 \pm 275.21$ & $4148.75 \pm 275.21$ \\
\hline 56 days & $4533.50 \pm 332.29 \mathrm{~B}$ & $5514.63 \pm 332.29 \mathrm{~A}$ \\
\hline \multirow[t]{2}{*}{84 days } & $10806.00 \pm 647.34$ & $8487.67 \pm 647.34$ \\
\hline & \multicolumn{2}{|c|}{ Stem mass $\left(\mathrm{kg} \mathrm{DM} \mathrm{ha}{ }^{-1}\right)$} \\
\hline 28 days & $2392.12 \pm 280.01$ & $2631.67 \pm 280.01$ \\
\hline 56 days & $2850.50 \pm 299.46$ & $3535.33 \pm 299.46$ \\
\hline \multirow{2}{*}{84 days } & $7126.21 \pm 619.61$ & $5089.50 \pm 619.61$ \\
\hline & \multicolumn{2}{|c|}{ Crude Protein $(\mathrm{CP}, \% \mathrm{DM})$} \\
\hline 28 days & $9.14 \pm 0.26$ & $8.72 \pm 0.25$ \\
\hline 56 days & $9.78 \pm 0.28$ & $9.45 \pm 0.29$ \\
\hline \multirow[t]{2}{*}{84 days } & $7.79 \pm 0.18 \mathrm{~B}$ & $8.87 \pm 0.18 \mathrm{~A}$ \\
\hline & \multicolumn{2}{|c|}{ Neutral detergent fiber (NDF, \% DM) } \\
\hline 28 days & $56.35 \pm 0.54$ & $56.21 \pm 0.52$ \\
\hline 56 days & $56.58 \pm 0.50 \mathrm{~B}$ & $58.28 \pm 0.52 \mathrm{~A}$ \\
\hline \multirow[t]{2}{*}{84 days } & $60.60 \pm 0.42 \mathrm{~A}$ & $59.22 \pm 0.41 \mathrm{~B}$ \\
\hline & \multicolumn{2}{|c|}{ Acid detergent fiber (ADF, \% DM) } \\
\hline 28 days & $28.26 \pm 0.40$ & $27.46 \pm 0.39$ \\
\hline 56 days & $27.82 \pm 0.33$ & $28.60 \pm 0.34$ \\
\hline \multirow[t]{2}{*}{84 days } & $30.37 \pm 0.30 \mathrm{~A}$ & $28.69 \pm 0.29 \mathrm{~B}$ \\
\hline & \multicolumn{2}{|c|}{ In vitro dry matter digestibility (IVDMD, \%) } \\
\hline 28 days & $74.09 \pm 0.85 \mathrm{~B}$ & $76.87 \pm 0.83 \mathrm{~A}$ \\
\hline 56 days & $76.48 \pm 0.65$ & $75.49 \pm 0.67$ \\
\hline
\end{tabular}


*Means in the same row, followed by different letters, differ by the T-test at $5 \%$.

The NDF content of leaves was similar ( $p \geq 0.05$ ) for both systems at 28 days, differing in the remaining evaluation period, being higher $(\mathrm{p} \leq 0.05)$ in the full sun system at 56 days and higher $(\mathrm{p} \leq$ $0.05)$ in the shaded system at 84 days (Table 3). The ADF contents of leaves, on the other hand, were similar $(\mathrm{p} \geq 0.05)$ between the systems at the beginning of the experimental period. However, at 84 days the ADF percentage was higher ( $\mathrm{p}$ $\leq 0.05$ ) in the shaded system (Table 3 ).

On all evaluated days, sward height ( $\mathrm{p} \leq$ 0.05 ) was taller in the shading system (Table 3) since the less incident light on the sward leads the plants to reallocate their leaves to higher strata to intercept luminosity more efficiently. For this, the plants lengthen their stems, contributing to increasing heights, stem elongation due to competition for light has already been observed by other authors. The shaded grasses undergo morphological changes to increase light capture efficiency, such as elongating leaves and stems, lowering leaf area index, increasing specific leaf area and prioritizing shoot growth over the root system, and having a lower tillering rate (Almeida et al. 2014).

Additionally, the plants lengthen their leaves, increasing the leaf area in an attempt to capture more light. Santos et al. (2018) studied Marandu grass monoculture (full sun), two eucalyptus planting spacings $(12 \times 2$ and $12 \times 4 \mathrm{~m})$, and three distances between Marandu grass and eucalyptus rows $(6,4$, and $2 \mathrm{~m})$ and found a decrease of leaf blade thickness of grass in higher levels of shade $(12 \times 2 \mathrm{~m}, 58.2 \%)$ probably due to a difference in the distribution of photoassimilates. These authors add that under a certain range of shading, a greater amount of photoassimilates is used by the plants to increase the leaf area to enhance the absorption of available light. Consequently, these leaves became more fibrous and less digestible as evidenced by the results obtained at 84 growing days, when lower $(\mathrm{P} \leq 0.05)$ IVDMD and CP content, as well as higher contents of NDF and ADF were obtained in the shaded system (Table 3).

The results regarding pasture quality at the end of the experimental period are related to pasture-free growth, not reflecting the nutritional value of a sward that was grazed or cut. Without defoliation, there was no tissue renewal causing the tiller to age with increasing contents of the cell wall components in detriment to the cellular content, hampering the nutritive value. Changes in plant tissues occur with growth, increasing the proportion of structural components such as cellulose, hemicellulose and lignin, and decreasing levels of soluble carbohydrates, proteins, minerals and vitamins, and the cellular content components (Reis \& Rodrigues 1993). This decreasing quality as forage matures, hinders animal intake, decreasing potential consumption and increasing NDF concentration as plant ages since NDF is more difficult to digest than the forage nonfibrous components, thus decreasing fiber digestion rates (Ball et al. 2001).

Moreover, forage grasses are more susceptible to shading conditions when the sward is being established as compared to the productive phase 
(Almeida et al. 2014) as observed in the present work. In general, under shading, forage grasses tend to have higher $\mathrm{CP}$ and lower cell wall contents and, consequently, higher dry matter digestibility (Almeida et al. 2014).

The results for the forage and roots masses in this study show that the Panicum maximum cv. BRS Zuri is adapted to shading of Eucalyptus grandis $\mathrm{x}$ Eucalyptus urophylla hybrids, planted in East-West single rows, spaced $14 \mathrm{~m}$ between rows and $3 \mathrm{~m}$ between trees, with an average height of $11.98 \mathrm{~m}$ and approximately two years of age. These masses, added to the $\mathrm{CP}$ contents of leaves indicate that this grass is adapted to low rainfall, inherent to the dry season. Further studies are needed to obtain definitive results on the quality of forage under shade in the different seasons of the year. The foliar fertilization applied at the beginning of seasons did not affect the evaluated parameters of BRS Zuri grass, therefore, further studies using higher application frequency are suggested to obtain conclusive results.

\section{ACKNOWLEDGMENTS}

To CNPq (National Council for Scientific and Technological Development), FUNDECT (Foundation for Support to the Development of Education, Science and Technology of the State of Mato Grosso do Sul), CAPES/PNPD (Coordination of Improvement of Higher-Level Personnel/ National Postdoctoral Program), and the State University of Mato Grosso do Sul, in Aquidauana, for the financial support to the project and the awarded grants. To Quimifol for providing the foliar fertilizer. This study was financed in part by the Coordination of Improvement of Higher-Level Personnel- Brazil (CAPES) - Finance code 001".

\section{REFERENCES}

ALMEIDA, R.G.; RANGEL, J.D.A.; CAVALCANTE, A.C.R.; ALVES, F.V. Sistemas silvipastoris: produção animal com benefícios ambientais. Embrapa Gado de Corte. In: Anais do 9th Congresso Nordestino de Produção Animal. Produção animal: novas diretrizes, Ilhéus: SNPA, [online], 3p. 2014.

ANDRÉ, T.B.; SANTOS, A.C.; OLIVEIRA, L.B.T. Growth and development of Mombassa grass grown in full sun and shade under nitrogen levels. Revista Engenharia na Agricultura [online], v.28, p.11-23, 2020.

ATKINSON, R.R.L.; BURRELL, M.M.; ROSE, K.E.; OSBORNE, C.P.; REES, M. The dynamics of recovery and growth: how defoliation affects stored resources. Proceedings of the Royal Society B: Biological Sciences [online], v.281, n.1783, 8p., 2014.

BALL, D.M.; COLLINS, M.; LACEFIELD, G.D.; MARTIN, N.P.; MERTENS, D.A.; OLSON, K.E.; PUTNAM, D.H.; UNDERSANDER, D.J.; WOLF, M.W. Understanding forage quality. American Farm Bureau Federation Publication [online], v.1, n.1, 2001.

BARRAGÁN-HERNÁNDEZ, W.A.; CAJAS-GIRÓN PHD, Y.S.

Bromatological and structural changes in Megathyrsus maximus in four silvopastoral arrangement systems. 
Ciencia y Tecnología Agropecuaria [online], v.20, n.2, p.231-258, 2019.

BARROS, J.S.; MEIRELLES, P.R.L.; GOMES, V.C.; PARIZ, C.M.; FACHIOLLI, D.F.; SANTANA, E.A.R.; GOMES, T.G.J.; COSTA, C.; CASTILHOS, A.M.; SOUZA, D.M.

Valor nutritivo do capim-Xaraés em três intensidades luminosas. Arquivo Brasileiro de Medicina Veterinária e Zootecnia [online], v.71, n.5, p.17031711, 2019.

CECATO, U.; CANO, C.C.P.; BORTOLO, M.; HERLING, V.R.; CANTO, M.W.D.; CASTRO, C.R.D.C. Teores de carboidratos não-estruturais, nitrogênio total e peso de raízes em Coastcross-1 (Cynodon dactylon (L.) Pers) pastejado por ovinos. Revista Brasileira de Zootecnia [online], v.30, n.3, p.644-650, 2001.

EMBRAPA, Empresa Brasileira de Pesquisa Agropecuária. Sistema Brasileiro de Classificação de Solos. Rio de Janeiro: Embrapa/CNPS; 2013, $306 p$.

FAVARE, H.G.; FILHO, A.D.A.T.; ABREU, J.G.; FAVARE, L.G.; COSTA, R.B.; PASA, M.C.; COUTO, L. Produção de forragem e distribuição espacial de árvores de pequi em sistema silvipastoril. Nativa [online], v.6, p.714-721, 2018.

GARCIA, J.B.; FERNANDES, T.A.; VAZ, R.Z. Efeito da fertilização foliar sobre a produção de biomassa e absorção de nutrientes na grama tanner. REDVET. Revista Electrónica de Veterinaria [online], v.18, n.10, p.1-11, 2017.
JANK, L.; SANTOS, M.F.; VALLE, C.B.; BARRIOS, S.; RESENDE, R. Novas alternativas de cultivares de forrageiras e melhoramento para a sustentabilidade da pecuária.

Embrapa Gado de Corte- Anais de congresso (ALICE). In: 4th Simpósio de Adubação e Manejo de Pastagens, 4th Simpósio de Produção Animal a Pasto, Dracena. Sustentabilidade do sistema produtivo [online], p.107-132, 2017.

LEMAIRE, G. The physiology of grass growth under tissue turnover. In: International symposium on animal production under grazing, p.117-144, 1997.

OLIVEIRA, F.R.L.; MOTA, V.A.; RAMOS, M.S.; SANTOS, L.D.T.; OLIVEIRA, N.J.F.; GERASEEV, L.C. Comportamento de Andropogon gayanus cv. 'planaltina' e Panicum maximum cv. 'tanzânia' sob sombreamento. Ciência Rural [online], v.43, n.2, p.348-354, 2013.

PACIULLO, D.S.C.; FERNANDES, P.B.; GOMIDE, C.A.D.M.; CASTRO, C.R.T.D.; SOBRINHO, F.D.S.; CARVALHO, C.A.B.D. The growth dynamics in Brachiaria species according to nitrogen dose and shade.

Revista Brasileira de Zootecnia [online], v.40, n.2, p.270-276, 2011.

PACIULLO, D.S.C.; GOMIDE, C.D.M.; MULLER, M.; PIRES, M.D.F.Á.; CASTRO, C.R.T. Potencial de produção e utilização de forragem em sistemas silvipastoris. In: Embrapa Gado de Leite-Artigo em anais de congresso (ALICE). In: SIMPÓSIO DE PECUÁRIA INTEGRADA, 1., 2014, Sinop, MT. Intensificação da produção 
animal em pastagens: anais. Brasília, DF: Embrapa, p.51-82, 2014. [online]

PACIULLO, D.S.C.; GOMIDE, C.A.M.; CASTRO, C.R.T.; MAURÍCIO, R.M.; FERNANDES, P.B.; MORENZ, M.J.F. Morphogenesis, biomass and nutritive value of Panicum maximum under different shade levels and fertilizer nitrogen rates. Grass and Forage Science, v.72, n.3, p.590-600, 2017.

PACIULLO, D.S.C.; GOMIDE, C.A.M. Manejo de pastagens tropicais em sistemas silvipastoris. In: ILPF: Inovação com integração de lavoura, pecuária e floresta. Embrapa Gado de Leite-Capítulo em livro técnico (INFOTECA-E) [online], p.389-403, 2019.

PEEL, M.C.; FINLAYSON, B.L.; MCMAHON, T.A. Updated world map of the Köppen-Geiger climate classification. Hydrology and Earth System Sciences [online], v.11, n.5, p.1633-1644, 2007.

PIETROSKI, M.; OLIVEIRA, R.; CAIONE, G. Adubação foliar de nitrogênio em capim mombaça (Panicum maximum cv. Mombaça. Revista de Agricultura Neotropical [online], v.2, n.3, p.49-53, 2015.

REIS, R.A.; RODRIGUES, L. Valor Nutritivo de plantas forrageiras. Jaboticabal:FUNEP, 1993, 26p.

SANTOS, M.V.; FERREIRA, E.A.; CRUZ, P.J.R.D.; RIBEIRO, V.H.V.; ALENCAR, B.T.B.; CABRAL, C.M.; FRANCINO, D.M.T.; ASPIAZÚ, I. Leaf anatomy of'Marandu'grass cultivated in plant arrangements in agrosilvopastoral systems. Pesquisa Agropecuária Brasileira, [online], v.53, n.12, p.1320-1328, 2018.

SCHJOERRING, J.K.; HUSTED, S.; MÄCK, G.; MATTSSON, M. The regulation of ammonium translocation in plants. Journal of Experimental Botany [online], v.53, n.370, p. 883890, 2002.

WHITE, L.M. Carbohydrate reserves of grasses: a review. Journal of Range Management [online], v.26, n.1, p.1318, 1973. 